\title{
Chapter 8 \\ Global Estimates of the Impacts of Grassland Degradation on Livestock Productivity from 2001 to 2011
}

\section{Ho-Young Kwon, Ephraim Nkonya, Timothy Johnson, Valerie Graw, Edward Kato and Evelyn Kihiu}

\begin{abstract}
In response to the needs for estimating the cost of grassland degradation to determine the cost of inaction and for identifying cost-effective strategies to address the consequent loss of livestock productivity, we developed a modeling framework where global statistics databases and remote sensing data/analyses coupled with empirical/statistical modeling are designed to quantify the global cost of grassland degradation. By using this framework, we identified grassland degradation hotspots over the period of 2001 to 2011 and estimated changes in livestock productivity associated with changes in grassland productivity within the hotspots. Ignoring environmental benefits and losses in live weight of livestock not slaughtered or sold, the cost of livestock productivity was estimated about 2007 US $\$ 6.8$ billion. Although on-farm cost is small in Sub-Saharan Africa due to the low livestock productivity, the impact on human welfare would be much more severe in the region where majority of the population is below the poverty line. This implies that addressing grassland degradation is even more urgent in the region, given the increasing demand for livestock products and the potential contribution to poverty reduction. Taking action toward grassland degradation could simultaneously reduce poverty and promote carbon sequestration while conserving socio-economic, cultural, and ecological benefits that livestock provide.
\end{abstract}

Keywords Empirical modeling - Global cost • Grassland degradation • Grazing biomass $\cdot$ Livestock productivity $\cdot$ Remote sensing data

\footnotetext{
H.-Y. Kwon ( $ه)$ · E. Nkonya · T. Johnson · E. Kato Environment \& Production Technology Division, International Food Policy Research Institute, 2033 K Street, NW, Washington, DC 20006-1002, USA e-mail: h.kwon@cgiar.org

V. Graw

Center for Remote Sensing of Land Surfaces (ZFL), University of Bonn, Walter Flex Str 3, D-53113 Bonn, Germany

E. Kihiu

Center for Development Research (ZEF), University of Bonn, Walter Flex Str 3, D-53113 Bonn, Germany 


\section{Introduction}

Global meat and dairy consumption is projected to increase by 173 and $158 \%$ from 2010 to 2050 and an even higher increase in meat and dairy consumption is expected for developing countries. This rapid increase in demand for livestock products would require corresponding increases in demand for animal feeds, which in turn would lead to conversion of high value biomes - such as forest to grazing lands - and overgrazing especially for grassland-based livestock production systems (Asner and Archer 2010). In fact, over the last few decades, grasslands have been degraded due to overgrazing and account for the largest extent of degradation among all major biomes considered. Steinfeld et al. (2006) estimated that about $20 \%$ of global pasture and $73 \%$ of the rangelands in the drylands have been degraded. About $70 \%$ of deforestation in the Amazon was due to expansion of pasture and a large part of the remaining $30 \%$ of cleared forests was due to feed crops expansion (ibid). Other studies also reported severe degradation in grazing biomes. Nabuurs (2004) estimated that about $5 \%$ of soil organic carbon has been lost from overgrazed or moderately degraded temperate and/or boreal grasslands. More recently, Le et al. (2014), Chap. 4, estimated that about $40 \%$ of grasslands experienced degradation between 1982 and 2006 by employing long-term data of remotely sensed Normalized Difference Vegetation Index (NDVI) as a proxy for global land degradation.

Degradation of grazing biomes poses a big threat to sustain and/or increase global livestock productivity, which serves multiple purposes including economic, social and ecological functions (Nabuurs 2004; Randolph et al. 2007). Livestock plays an especially important role in the livelihoods of the rural poor households, two-thirds of whom keep livestock (Livestock in Development 1999). Low-income rural households also use livestock as living "savings accounts" (Moll 2005) and insurance against risks and shocks (Hoddinott 2006). Additionally, livestock is used to strengthen social bonds (e.g. dowry) and serve as an indicator of social importance (Kitalyi et al. 2005). In Sub-Saharan Africa (SSA), animal and human power account for $80 \%$ of total farm energy (FAO 2011a). The multiple objectives of livestock suggests that the sector has a large potential to contribute to poverty reduction efforts in developing countries. Such potential is amplified by the increasing demand for livestock products as incomes and food tastes and preferences change in middle and low income countries. Currently livestock accounts for about 13 and $28 \%$ of the global caloric and protein intakes, respectively (FAO 2011b). Livestock also plays a vital role in maintaining soil nutrients in cropland, as livestock manure accounts for 54-64\% of total nitrogen applications and $64 \%$ of phosphorus (Sheldrick et al. 2004; Potter and Ramankutty 2010). ${ }^{1}$ Given the important role of livestock and the severe land degradation in grasslands, it is

\footnotetext{
${ }^{1}$ Sheldrick et al. (2004) estimate that global total recoverable $\mathrm{N}$ and $\mathrm{P}$ from manure is respectively 93.6 $\mathrm{TgN}_{\text {year }}{ }^{-1}$ and $21.7 \mathrm{TgP}_{\text {year }}{ }^{-1}$ of the total $171.8 \mathrm{TgN}$ and $34.4 \mathrm{TgP}$ year ${ }^{-1}$ consumption global of $\mathrm{N}$ and $\mathrm{P}$. Note, one terragram $(\mathrm{Tg})=$ one million tons.
} 
necessary to estimate the cost of land degradation in grazing biomes to determine the cost of inaction and to identify cost-effective strategies to address the consequent loss of livestock productivity.

In response to these needs, we developed a modeling framework where global statistics databases and remote sensing data/analyses coupled with empirical/statistical modeling approach are designed to estimate global impacts of land degradation on spatial and temporal changes of agronomic and environmental indicators (e.g. productivity and soil carbon stock) in both croplands and grasslands. In this chapter, we focused to quantify the cost of grassland degradation on a global scale by using this framework. This type of work contributes to literature in two ways. Firstly, our modeling framework employs empirical/statistical models to estimate the loss of grassland biomass productivity. This simple approach allows estimating a complex system (Wainwright and Mulligan 2005). It also utilizes easily available remote-sensing data to estimate changes in biomass productivity so that it could allow building modeling systems for low-cost global and regional monitoring of grazing land degradation and improvement. Secondly, to the best of our knowledge, this is the first global assessment of the cost of grazing land degradation. Many past global studies have largely dwelt on biophysical assessments of grazing land degradation (e.g. Steinfeld et al. 2006). The few past global or regional studies on the cost of grassland degradation have largely been based on review of literature (e.g. Dregne 2002; Requier-Desjardins 2006) or covering a specific area (e.g. Quinlan 1995; Harris 2010).

This chapter detailed procedures included in our modeling framework such as (i) identifying land degradation hotspots where inter-annual mean NDVI over the historical period of 2001 to 2011 has a declining trend, (ii) classifying statistical models to estimate changes in biomass from NDVI based on biome, (iii) developing simple relationships between the NDVI trend and livestock productivity within the hotspots, and iv) estimating changes in livestock productivity. Finally we reported the costs of grassland degradation associated with changes in livestock productivity.

\section{Modeling Procedures}

\section{Identifying Land Degradation Hotspots in Grasslands}

The identification of land degradation hotspots within grasslands was based on time series analysis of global Moderate Resolution Imaging Spectroradiometer (MODIS) NDVI data (MYD13C1) from 2001 to 2011 with a temporal resolution of 16 days and a spatial resolution of $0.05^{\circ}(5.6 \times 5.6 \mathrm{~km})$. MODIS was launched in February 2000 and provides a cloud-free global coverage of NDVI data (Huete et al. 2011) (Table 8.1). The time series analysis for this study used the year 2001 as a starting point and covered an equal number of 16-day datasets for each year of the analysis. The trend, depicting the slope of the linear regression, was calculated for the period 
of 2001 to 2011 when the datasets regarding geographic, demographic, economic, technological, institutional and cultural factors (e.g. climate and agricultural practices, population density, poverty, absence of secure land tenure, lack of market access) were available.

Mean annual values of NDVI were calculated for every year from 2001 to 2011. Based on these, the slope of the linear regression was calculated to get the NDVI trend for each pixel. The dataset was corrected for rainfall because it is the dominant causative factor having the highest impact on vegetation greenness which is represented by NDVI (Nicholson et al. 1990; Hermann et al. 2005). It is important to remove this influence, since we are only interested in anthropogenic causes of land degradation and not natural causes such as drought or natural vegetation changes, both of which can caused by fluctuations in rainfall.

The same time period used for the NDVI analysis was taken into account for the rainfall analysis based on monthly precipitation data by the University of East Anglia's Climatic Research Unit time-series data (CRU 3.1) (Jones and Harris 2008), which has a spatial resolution of $0.5^{\circ}(56 \times 56 \mathrm{~km})$, much coarser than the one of the NDVI data (Table 8.1). Considering that (i) high resolution of historical precipitation data comparable to the resolution of the NDVI data has not been developed, (ii) the CRU data is the most reliable precipitation data on the global scale covering the time period of our study, and (iii) the minimum rainfall station density required to adequately describe annual rainfall varies from 200 to $800 \mathrm{~km}$ depending on latitude/longitude location (New et al. 2000), we assumed that the CRU data still works as a way of approximating rainfall effects on vegetation. To correct the NDVI dataset for rainfall, statistically significant trends between 2001 and $2011(P<0.05)$ were calculated. Again mean annual values were composed on which significant trends were calculated for every pixel. All significant positive and negative pixels were then masked in the final dataset. Since the rainfall data has a coarser resolution than the NDVI data, some NDVI pixels which might not be directly influenced by rainfall were masked.

A classified dataset for land cover and land use on a global level, Globcover 2004-2006 data (Bicheron et al. 2008), was used to extract all grassland areas ${ }^{2}$ within land degradation hotspots (Table 8.1). Globcover 2004-2006 data was used because it best approximated the extent of grasslands during the study period from 2001 to 2011. Derived from remote sensing data between 2004 and 2006 this global land cover map was generated with a spatial resolution of $300 \mathrm{~m}$. Since not all grasslands contain active grazing, especially when estimated from remote sensing imagery, a grazing land extent was used to further narrow down the areas of degradation that would most affect livestock. This was done by using the same grazing land extent based on the Gridded Livestock of the World (GLW) dataset (See Gathering datasets for livestock productivity). Thus, the final global extent

\footnotetext{
${ }^{2}$ Two classes of Globcover data-140: Closed to open (>15\%) herbaceous vegetation (grassland, savannas or lichens/mosses) and 180: Closed to open ( $>15 \%)$ grassland or woody vegetation on regularly flooded or waterlogged soil—Fresh, brackish or saline) — are categorized as grassland.
} 
Table 8.1 Datasets used for vegetation trend analysis in grasslands

\begin{tabular}{l|l|l|l|l}
\hline Data & Source & $\begin{array}{l}\text { Temporal } \\
\text { resolution }\end{array}$ & $\begin{array}{l}\text { Spatial } \\
\text { resolution }\end{array}$ & Data record \\
\hline $\begin{array}{l}\text { Vegetation } \\
\text { (MODIS-NDVI) }\end{array}$ & $\begin{array}{l}\text { LP DAAC } \\
\text { (Land Processes } \\
\text { Distributed Active } \\
\text { Archive Center) (2011) }\end{array}$ & 16 days & $0.05^{\circ}$ & Year 2001-2011 \\
\hline Rainfall (CRU 3.1) & Jones and Harris (2008) & Monthly & $0.5^{\circ}$ & Year 2001-2011 \\
\hline $\begin{array}{l}\text { Land cover/use } \\
\text { (Globcover 2004-2006) }\end{array}$ & Bicheron et al. (2008) & & $300 \mathrm{~m}$ & Year 2004-2006 \\
\hline
\end{tabular}

Source The authors

includes areas classified as grassland, where active grazing is occurring, within land degradation hotpots.

\section{Deriving Grassland Productivity from Remote Sensing Imagery Data and Statistical Models}

Many studies have developed statistical models to estimate grassland productivity by using remote sensing imagery data of NDVI and net primary productivity (NPP) (Table 8.2). Although there seems to be no consensus on the universally accepted model to derive absolute values of grassland productivity on a global scale, NDVI or NPP are still good proxies for grassland productivity. Accordingly, we used the linear regression model results reported in Table 8.2 to estimate grazing biomass. As far as possible, we used the regression results in regions and agro-ecological zones where it was derived.

When the regression results were compared with the actual biomass productivity reported in different agro-ecological zones (AEZ), they showed that the predictive power of the model was reasonably accurate as only 6 of the 21 AEZ-level predicted values fell outside the $95 \%$ interval (Table 8.3).

\section{Gathering Datasets for Livestock Productivity}

FAO and the Environmental Research Group Oxford published the first version of GLW dataset in order to address important issues of the livestock sector, such as increased pressures on natural resources and the environment (2007). The GLW provides livestock densities of cattle, buffalo, sheep, goats, pigs, and poultry/chickens modeled at a spatial resolution of $0.05^{\circ}$, based on statistical relationships between observed densities within administrative units derived from survey and census data, and several explanatory variables (e.g. a time-series of remotely sensed satellite data relating to climate and the environment) (Robinson et al. 2014) (Table 8.4). 
Table 8.2 Literature review on statistical models to predict biomass as a function of remote sensing imagery data in grasslands

\begin{tabular}{|c|c|c|c|}
\hline Region & Relational equation & $\mathrm{R}^{2}$ & Source \\
\hline $\begin{array}{l}\text { China (Meadow } \\
\text { Steppe) }\end{array}$ & Biomass $_{\text {grass }}=1478 \times \mathrm{NDVI}^{2.56}$ & 0.60 & $\begin{array}{l}\text { Jin et al. } \\
(2014)\end{array}$ \\
\hline China (Typical Steppe) & Biomass $_{\text {grass }}=910 \times \mathrm{NDVI}^{1.627}$ & 0.57 & $\begin{array}{l}\text { Jin et al. } \\
(2014)\end{array}$ \\
\hline China (Desert Steppe) & Biomass $_{\text {grass }}=487 \times \mathrm{NDVI}-27.719$ & 0.49 & \begin{tabular}{|l} 
Jin et al. \\
$(2014)$
\end{tabular} \\
\hline China (Arid-Semi arid) & Biomass $_{\text {grass }}=896 \times \mathrm{NDVI}-75.5$ & 0.46 & $\begin{array}{l}\text { Ren and } \\
\text { Zhou } \\
(2014)\end{array}$ \\
\hline $\begin{array}{l}\text { Mongolia (Arid-Semi } \\
\text { arid) }\end{array}$ & Biomass $_{\text {grass }}=1.097 \times \mathrm{NPP}-4.776$ & 0.55 & $\begin{array}{l}\text { Zhao } \\
\text { et al. } \\
(2014)\end{array}$ \\
\hline $\begin{array}{l}\text { Madagascar (Humid } \\
\text { subtropical) }\end{array}$ & Biomass $_{\text {forage }}=867.9 \times \mathrm{NDVI}-329.2$ & 0.61 & $\begin{array}{l}\text { Rahetlah } \\
\text { et al. } \\
(2014)\end{array}$ \\
\hline $\begin{array}{l}\text { Madagascar (Humid } \\
\text { subtropical) }\end{array}$ & Biomass $_{\text {forage }}=0.143 \times \mathrm{e}^{3.812 \times \mathrm{NDVI}}$ & 0.73 & $\begin{array}{l}\text { Rahetlah } \\
\text { et al. } \\
(2014)\end{array}$ \\
\hline Montana-USA & Biomass $_{\text {forage }}=25 \times$ NDVI -2739 & 0.63 & $\begin{array}{l}\text { Thoma } \\
\text { et al. } \\
(2002)\end{array}$ \\
\hline India & $\begin{array}{l}\text { Biomass estimated from linear regression of } \\
\text { NPP }\end{array}$ & 0.77 & $\begin{array}{l}\text { Roy and } \\
\text { Ravan } \\
(1996)\end{array}$ \\
\hline $\begin{array}{l}\text { Canada, Finland, } \\
\text { Norway, Russia, USA, } \\
\text { Sweden }\end{array}$ & $\begin{array}{l}\text { Biomass estimated from linear regression of } \\
\text { Advanced Very High Resolution } \\
\text { Radiometer (AVHRR) }\end{array}$ & & $\begin{array}{l}\text { Dong } \\
\text { et al. } \\
(2003) \\
\end{array}$ \\
\hline Canada & $\begin{array}{l}\text { Biomass estimated form multiple regression } \\
\text { and artificial neutral networks as a function } \\
\text { of SPOT Vegetation }\end{array}$ & & $\begin{array}{l}\text { Fraser } \\
\text { and Li } \\
(2002)\end{array}$ \\
\hline Finland and Sweden & $\begin{array}{l}\text { Biomass estimated from non-Linear } \\
\text { regression and K-Nearest Neighbor as a } \\
\text { function of Landsat-Tm }\end{array}$ & & $\begin{array}{l}\text { Tomppo } \\
\text { et al. } \\
(2002)\end{array}$ \\
\hline
\end{tabular}

Source The authors

Along with the GLW, we obtained the map of livestock production systems developed by FAO and the International Livestock Research Institute (Robinson et al. 2011). This map is an extension of previous classification schemes, made by Sere and Steinfeld (1996) into global coverage with better quality and higher spatial resolution input data such as land cover, length of growing period, highland and temperate areas, human population, and irrigated areas. By overlaying these two maps, we summarized livestock density in each livestock production system (Table 8.4).

Furthermore we acquired estimates of supply for animal-source foods (beef, milk, mutton, pork, poultry meat, and eggs) that are spatially disaggregated based 
Table 8.3 Validation of biomass productivity model

\begin{tabular}{|c|c|c|c|}
\hline \multirow[t]{3}{*}{ Agro-ecological zone } & \multicolumn{2}{|c|}{ Predicted biomass productivity } & $\begin{array}{l}\text { Observed biomass } \\
\text { productivity }\end{array}$ \\
\hline & \multicolumn{3}{|c|}{ Dry matter tons/ha } \\
\hline & Predicted & $\begin{array}{l}\text { Standard } \\
\text { deviation }\end{array}$ & Predicted \\
\hline Boreal & 1.00 & 0.44 & $<0.5$ \\
\hline Subtropic-cool/Semi-arid & 0.95 & 0.61 & $<0.5$ \\
\hline Subtropic-cool/arid & 0.66 & 0.42 & $0.5-1$ \\
\hline Subtropic-cool/humid & 5.30 & 2.98 & $1-1.5$ \\
\hline Subtropic-cool/sub-humid & 1.85 & 1.58 & $1-1.5$ \\
\hline Subtropic-warm/Semi-arid & 3.34 & 3.58 & $-1-1.5$ \\
\hline Subtropic-warm/arid & 0.88 & 0.52 & $5.1-18$ \\
\hline Subtropic-warm/humid & 12.18 & 4.41 & $0.5-1$ \\
\hline Subtropic-warm/sub-humid & 6.08 & 4.08 & $5.1-18$ \\
\hline Temperate/Semi-arid & 0.94 & 0.49 & $5.1-18$ \\
\hline Temperate/arid & 0.51 & 0.34 & $<0.5$ \\
\hline Temperate/humid & 1.25 & 0.42 & $<0.5-1$ \\
\hline Temperate/sub-humid & 2.32 & 1.51 & $0.7-3.1$ \\
\hline Tropic-cool/Semi-arid & 1.50 & 0.68 & $0.7-3.1$ \\
\hline Tropic-cool/arid & 0.69 & 0.57 & $<0.5$ \\
\hline Tropic-cool/humid & 4.24 & 2.30 & $0.5-1$ \\
\hline Tropic-cool/sub-humid & 3.44 & 1.44 & $1-1.5$ \\
\hline Tropic-warm/Semi-arid & 1.76 & 0.59 & $<0.5$ \\
\hline Tropic-warm/arid & 0.90 & 0.63 & $0.5-1$ \\
\hline Tropic-warm/humid & 4.67 & 1.72 & $1-1.5$ \\
\hline Tropic-warm/sub-humid & 3.98 & 1.39 & $1-1.5$ \\
\hline
\end{tabular}

Notes Predicted outside the $95 \%$ confidence interval are emphasized in bold

Table 8.4 Datasets for livestock productivity

\begin{tabular}{l|l|l|l}
\hline Data & Source & $\begin{array}{l}\text { Spatial } \\
\text { resolution }\end{array}$ & $\begin{array}{l}\text { Data } \\
\text { record }\end{array}$ \\
\hline Livestock density & Robinson et al. (2014) & $0.05^{\circ}$ & $\begin{array}{l}\text { Year } \\
2000\end{array}$ \\
\hline Livestock production system & Robinson et al. (2011) & $0.05^{\circ}$ & $\begin{array}{l}\text { Year } \\
2000\end{array}$ \\
\hline $\begin{array}{l}\text { Supply and demand for } \\
\text { animal-source foods }\end{array}$ & $\begin{array}{l}\text { Robinson and Pozzi } \\
(2011)\end{array}$ & $0.05^{\circ}$ & $\begin{array}{l}\text { Year } \\
2000\end{array}$ \\
\hline
\end{tabular}

Source The authors

on information derived from the GLW and models for livestock growth and off-take (Robinson and Pozzi 2011). In the latter models, livestock production and off-take rates, varying across different agro-ecological zones and livestock production systems, are parameterized differentially for different zones or systems using the 
herd growth model within the Livestock Development Planning System Version 2 (Lalonde and Sukigara 1997).

Given that we dealt with grazing biomass, our analysis focused on the grassland-based (grazing) livestock production systems, in which more than $90 \%$ of the dry matter intake is obtained from grasslands (Steinfeld et al. 2006). Accordingly, we considered only grazing livestock, namely buffalo, cattle, goat, and sheep. According to Steinfeld et al. (2006), the grazing production systems account for $28 \%$ of the livestock population and covers $26 \%$ of the ice-free land area (ibid.) (Table 8.5). To avoid double counting cost of land degradation considered in Chap. 6, we do not consider livestock feeding other biomes other than grasslands. This includes about $72 \%$ of the livestock population (Table 8.5). Our study also considers degraded "static" grasslands - that is grassland area that did not undergo land use cover change from 2001 to 2011. Degraded grasslands account for $10 \%$ of the grassland area and about $6 \%$ of total livestock population (Table 8.6). SSA reported the largest population of livestock on degraded grassland while Central Asia reported the largest degraded grazing area as percent total grassland area (Table 8.6).

\section{Estimating Changes in Livestock Productivity}

To estimate changes in livestock productivity, we first resampled all datasets to a spatial resolution of $0.08^{\circ}$ to link to global grids containing unique IDs for each grid cell, developed by HarvestChoice at the International Food Policy Research Institute. Grassland productivity derived from NDVI and statistical models (Table 8.2) was combined with conversion factors developed by Wirsenius et al. (2010) and Bouwman et al. (2005) to estimate the impact of grazing land degradation on livestock productivity (Eq. 8.1). As shown in Fig. 8.1, Wirsenius et al. (2010) and Bouwman et al. (2005)'s conversion factors are comparable in North America but vary widely in SSA. However, Bouwman et al. (2005)'s conversion factors are disaggregated across feeding systems - namely pastoral and mixed and landless (zero-grazed) feeding systems. Unfortunately we only used Wirsenius et al. (2010) since we do not have global data on feeding systems at the resolution used in this study.

The impact of degradation within grazing biomass on livestock productivity has to take into account two important aspects that affect animal food intake:

i. Non-grass feeds-which include: feed supplements, food crops and its by-products, crop residues and fodder crops, scavenging (road-side grazing, household wastes, feedstuffs from backyard farming, etc.), and animal products. Contribution of non-grass DMI vary widely across regions. For example in the Sahelian region of SSA, shrub, tree and crop residues contribute $33 \%$ of livestock biomass requirements (Le Houérou and Hoste 1977; Pieri 1989) even though such feeding systems are regarded as $100 \%$ grassland-based. To take 
Table 8.5 Livestock production systems and corresponding livestock populations and production

\begin{tabular}{l|l|l|l|l|l}
\hline & Grazing & $\begin{array}{l}\text { Rainfed } \\
\text { mixed }\end{array}$ & $\begin{array}{l}\text { Irrigated } \\
\text { mixed }\end{array}$ & Zero-grazed/industrial & Total \\
\hline
\end{tabular}

Million heads-average 2001-2003

\begin{tabular}{l|l|l|l|l|l}
\hline $\begin{array}{l}\text { Cattle and } \\
\text { buffaloes }\end{array}$ & 406 & 641 & 450 & 29 & 1526 \\
\hline Sheep and goats & 590 & 632 & 546 & 9 & 1777 \\
\hline $\begin{array}{l}\text { Tropical livestock } \\
\text { units (TLU) }\end{array}$ & 343 & 512 & 370 & 21 & 1246 \\
\hline$\%$ of total & 27.5 & 41.1 & 29.7 & 1.7 & \\
\hline
\end{tabular}

Production (Million tons) - average 2001-2003

\begin{tabular}{l|r|r|r|r|r}
\hline Beef & 14.6 & 29.3 & 12.9 & 3.9 & 60.7 \\
\hline Mutton & 3.8 & 4.0 & 4.0 & 0.1 & 11.9 \\
\hline Pork & 0.8 & 12.5 & 29.1 & 52.8 & 95.2 \\
\hline Poultry meat & 1.2 & 8.0 & 11.7 & 52.8 & 73.7 \\
\hline Milk & 71.5 & 319.2 & 203.7 & - & 594.4 \\
\hline Eggs & 0.5 & 5.6 & 17.1 & 35.7 & 58.9 \\
\hline
\end{tabular}

Notes Livestock considered include buffalo, cattle, goats and sheep. Conversion factor to TLU buffaloes $=0.7$; cattle $=0.7$; goats and sheep $=0.1$. Grazing: $>90 \%$ of dry matter intake (DMI) obtained from grasslands; Rainfed mixed: $>10 \%$ of DMI come from crop residues and non-livestock farming activities and $>90 \%$ of the value of non-livestock farm production comes from rainfed land use; Irrigated mixed: $>10 \%$ of value of non-livestock farm production comes from irrigated land use; Landless (zero-grazed)/industrial: $<10 \%$ of DMI is farm produced Source Calculated from Steinfeld et al. (2006)

this into account we net out the impact of non-grass intake using Bowman et al. (2003) data on feed composition (Fig. 8.2). However, we compute one conversion factor weighted by the contribution of each feeding system to total production of meat and milk.

ii. Grass biomass that is not all consumed by animals. Studies have shown that the consumable forage of grasses is only one-third of the above-ground biomass (Penning de Vries and Djitèye 1982; de Leeuw and Tothill 1993).

Given the above discussion, the cost of milk production loss due to land degradation $\left(C L D_{m}\right)$ is given by:

$$
\begin{gathered}
C L D_{m}=\sum_{i=1}^{I}\left[D M I_{t=2001}-D M I_{t=2010}\right] \theta_{m} x_{t} P_{m} \\
D M I_{t}=\operatorname{biom}_{t} \gamma \kappa
\end{gathered}
$$

where $D M I_{t}=$ dry matter intake (tons) in year $t$ in pixel i; $\theta_{m}=$ conversion factor of grass DMI to the fresh weight of milk; $P_{m}=$ price of milk per ton; biom $_{t}=$ grass biomass production (DM) in year $t ; \gamma=$ contribution of grass to total feed intake; $x_{t}=$ number of milking cows in pixel $i$; and $\kappa=$ share of above ground grass biomass actually consumed by livestock. 
Table 8.6 Livestock population on degraded grazing lands across regions

\begin{tabular}{l|l|l|l|l}
\hline & $\begin{array}{l}\text { Degraded } \\
\text { grazing } \\
\text { area } \\
\text { (million } \\
\text { ha) }\end{array}$ & $\begin{array}{l}\text { Degraded } \\
\text { area of } \\
\text { total } \\
\text { grazing } \\
\text { area }(\%)\end{array}$ & $\begin{array}{l}\text { Livestock } \\
\text { population on } \\
\text { degraded grazing } \\
\text { area (million } \\
\text { TLU) }\end{array}$ & $\begin{array}{l}\text { Livestock population on } \\
\text { degraded grazing area of } \\
\text { total livestock population } \\
\text { global (\%) }\end{array}$ \\
\hline SSA & 339.8 & 18.5 & 23.32 & 14.0 \\
\hline LAC & 157.36 & 8.1 & 14.63 & 6.4 \\
\hline NAM & 129.71 & 7.9 & 12.59 & 12.5 \\
\hline East Asia & 77.32 & 8.9 & 3.69 & 2.4 \\
\hline Oceania & 153.15 & 18.3 & 1.35 & 3.6 \\
\hline $\begin{array}{l}\text { South } \\
\text { Asia }\end{array}$ & 3.42 & 0.7 & 0.14 & 0.1 \\
\hline $\begin{array}{l}\text { Southeast } \\
\text { Asia }\end{array}$ & 9.55 & 3.8 & 1.14 & 2.9 \\
\hline $\begin{array}{l}\text { East } \\
\text { Europe }\end{array}$ & 26.77 & 1.5 & 0.73 & 1.2 \\
\hline West & 17.87 & 5.1 & 4.95 & 5.5 \\
Europe & 153.68 & 47.3 & 3.39 & 26.7 \\
\hline $\begin{array}{l}\text { Central } \\
\text { Asia }\end{array}$ & 36.58 & 10.8 & 1.78 & 2.9 \\
\hline NENA & 1105.21 & 10.3 & 67.7 & 5.7 \\
\hline Global & & & & \\
\hline
\end{tabular}

Notes Livestock considered include buffalo, cattle, goats and sheep. Conversion factor to $T L U$ buffaloes $=0.7$, cattle $=0.7$, boats and sheep $=0.1$. SSA Sub-Saharan Africa; LAC Latin America and Caribbean; NAM North America; NENA Near East and North Africa

Sources Livestock population—FAO 2005 livestock density: http://www.fao.org/ag/aga/glipha/ index.jsp

Likewise, the loss of meat production due to land degradation $\left(C L D_{b}\right)$ is given by

$$
C L D_{b}=\left[D M I_{t=2001}-D M I_{t=2010}\right] \theta_{b} x_{t} \tau_{t} P_{b}
$$

where $P_{b}=$ price of meat per ton; $\theta_{b}=$ conversion factor of grass DMI to the fresh weight of meat; $\tau_{t}=$ off-take rate; other variables are as defined above.

We only consider on-farm losses including milk production and off-take rate for meat and ignore the loss of live weight of livestock not slaughtered or sold since such loss is not liquidated and eventually affects human welfare. We also ignore the impact of degradation on livestock health, parturition, and mortality rates due to lack of data as well as loss of carbon sequestration and other environmental and ecological services provided by grasslands. The ignored costs of grazing land degradation are large. For example, Chap. 17 shows that in Niger, $82 \%$ of the total cost of degradation of grazing lands was due to loss of carbon sequestration. This means our results are conservative estimates. 


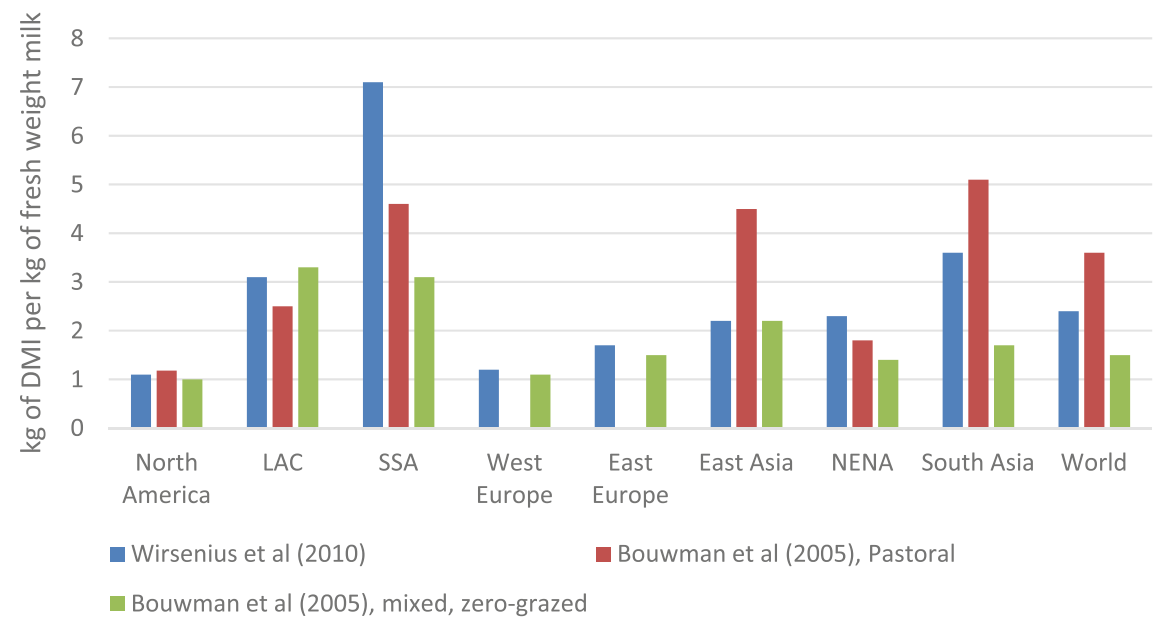

Fig. 8.1 Feed conversion factor to unit of milk and beef across regions. Note DMI is intake of all food categories. LAC Latin American Countries; SSA Sub-Saharan Africa; NENA Near East and North Africa

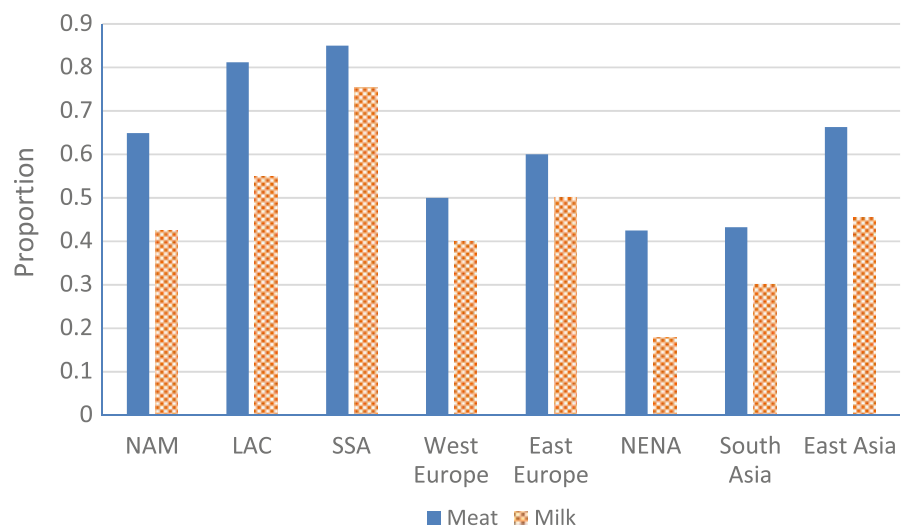

Fig. 8.2 Share of grass to total dry matter intake of meat and dairy ruminants. Note Meat whole carcass from all animal categories and the share of intake is weighted by the contribution pastoral and mixed and zero-grazed feeding systems to total production. NAM North America; LAC Latin American Countries; SSA Sub-Saharan Africa; NENA Near East and North Africa

\section{Results and Discussion}

Ignoring the environmental benefits of carbon sequestration and the loss in live weight of livestock that were not slaughtered or sold, the cost of livestock productivity was about 2007 US $\$ 6.8$ billion (Table 8.7). North America accounts for about $55 \%$ of the loss due to the severe land degradation in the region and the high 
Table 8.7 Cost of loss of milk and meat production due to land degradation of grazing biomass

\begin{tabular}{l|l|l|l|l}
\hline Region & Milk & Meat & $\begin{array}{l}\text { Total } \\
\text { loss }\end{array}$ & $\begin{array}{l}\% \text { of global } \\
\text { loss }\end{array}$ \\
\hline 2007 US\$ billion \\
\hline SSA & 0.753 & 0.059 & 0.812 & 11.9 \\
\hline LAC & 0.928 & 0.073 & 1.000 & 14.7 \\
\hline NAM & 3.473 & 0.273 & 3.746 & 55.0 \\
\hline East Asia & 0.094 & 0.051 & 0.145 & 2.1 \\
\hline Oceania & 0.083 & 0.171 & 0.255 & 3.7 \\
\hline South Asia & 0.011 & 0.000 & 0.011 & 0.2 \\
\hline $\begin{array}{l}\text { Southeast } \\
\text { Asia }\end{array}$ & 0.102 & 0.002 & 0.103 & 1.5 \\
\hline East Europe & 0.060 & 0.037 & 0.098 & 1.4 \\
\hline $\begin{array}{l}\text { West } \\
\text { Europe }\end{array}$ & 0.402 & 0.125 & 0.527 & 7.7 \\
\hline $\begin{array}{l}\text { Central } \\
\text { Asia }\end{array}$ & 0.066 & 0.003 & 0.068 & 1.0 \\
\hline NENA & 0.005 & 0.039 & 0.044 & 0.6 \\
\hline Global & 5.978 & 0.832 & 6.809 & 11.9 \\
\hline Note: SSA Sub-San
\end{tabular}

Note: SSA Sub-Saharan Africa; LAC Latin American Countries; NAM North America; NENA Near East and North Africa

livestock productivity and off take rate. For example, Table 8.8 shows that the loss of one ton of grazing biomass leads to a loss of US\$98 in SSA but the same leads to a loss \$514 in North America. The low off take rate in SSA also reduces the loss of meat productivity since we ignore the live weight loss of not culled animals.

Loss of milk production contributes $99 \%$ of the total cost of grazing biomass degradation mainly due to its high sensitivity to the loss of grazing biomass. For example, loss of one DM ton of grazing biomass in North America leads to a loss of $909 \mathrm{~kg}$ of milk but only about $42 \mathrm{~kg}$ of meat respectively worth US\$435 and US\$79 (Table 8.8). As noted above, the low offtake rate of meat also contributes to its low contribution to the total loss.

Overall, the cost of land degradation is small compared to the area covered by grazing biomass. The low productivity of livestock in developing countries is part of the reason for the low cost. Additionally, other sources of dry matter consumption are not taken into account. These include animal feeds and crop-based DMI. And, as discussed in the methods section, it is only a third of the grassland biomass that is included in the computation of the cost of grazing biomass degradation due to the overlay of degradation and grazing areas. In addition, the loss of carbon sequestration and other ecosystem services are not considered. The livestock population in the grassland considered is also low as it accounts for only $28 \%$ of the total livestock population (Table 8.5), though it covers $20 \%$ of the ice-free global land area (Steinfeld et al. 2006).

Milk and beef productivity in the 2001-2011 period showed a statistically significant upward trend for all regions. A sample of the trend line is reported in Table 8.9 illustrating an upward trend of productivity for both low and high income regions. 
Table 8.8 Annual cost of milk and meat productivity due to loss of 1 ton of grazing biomass

\begin{tabular}{|c|c|c|c|c|c|c|c|}
\hline \multirow[t]{2}{*}{ Region } & \multicolumn{2}{|c|}{ Price per ton } & \multicolumn{2}{|c|}{$\begin{array}{l}\text { Annual } \\
\text { productivity } \\
\text { loss (kg/ton } \\
\text { of dry } \\
\text { matter) }\end{array}$} & \multicolumn{3}{|c|}{ Cost of loss (US\$) } \\
\hline & Milk & Meat & Milk & Meat & Milk & Meat & Total \\
\hline SSA & 503 & 2775 & 140.8 & 9.8 & 71 & 27 & 98 \\
\hline LAC & 261 & 1550 & 322.6 & 15.6 & 84 & 24 & 109 \\
\hline NAM & 479 & 1907 & 909.1 & 41.7 & 435 & 79 & 514 \\
\hline East Asia & 581 & 2590 & 454.5 & 20.4 & 264 & 53 & 317 \\
\hline Oceania & 270 & 2812 & 454.5 & 20.4 & 123 & 57 & 180 \\
\hline South Asia & 305 & 1696 & 277.8 & 6.8 & 85 & 12 & 96 \\
\hline $\begin{array}{l}\text { Southeast } \\
\text { Asia }\end{array}$ & 746 & 2955 & 277.8 & 6.8 & 207 & 20 & 228 \\
\hline $\begin{array}{l}\text { East } \\
\text { Europe }\end{array}$ & 368 & 3723 & 588.2 & 27.8 & 217 & 103 & 320 \\
\hline $\begin{array}{l}\text { West } \\
\text { Europe }\end{array}$ & 476 & 4829 & 833.3 & 38.5 & 397 & 186 & 582 \\
\hline $\begin{array}{l}\text { Central } \\
\text { Asia }\end{array}$ & 255 & 1676 & 277.8 & 6.8 & 71 & 11 & 82 \\
\hline NENA & 413 & 5979 & 434.8 & 20.8 & 179 & 125 & 304 \\
\hline Global & 395 & 2472 & 416.7 & 20.0 & 165 & 49 & 214 \\
\hline
\end{tabular}

Note: SSA Sub-Saharan Africa; LAC Latin American Countries; NAM North America; NENA Near East and North Africa Source Computed from Fig. 8.1

This pattern is similar to what is reported on cropland in Chap. 6 of this volume. The seemingly conflicting results are due to farmers' efforts to compensate the loss due to land degradation by using other productivity enhancing inputs and technologies.

Figure 8.3 reports the cost of land degradation and illustrates the high cost in North America, Latin America and SSA.

Table 8.9 Trendline regression of cow milk \& cattle carcass weight for selected regions for the period of 2001 to 2011

\begin{tabular}{l|l|l}
\hline Region & Carcass weight/head & Milk yield/cow \\
\hline SSA & 0.004 & 0.014 \\
\hline LAC & 0.0036 & 0.046 \\
\hline NAM & 0.0017 & 0.148 \\
\hline South Asia & 0.0009 & 0.019 \\
\hline West Europe & 0.049 & 0.263 \\
\hline
\end{tabular}

Note Regression trendline: $\mathrm{Y}=\beta_{1}+\beta_{2}$ year $+\varepsilon$ where $\beta_{1}=$ constant, $\beta_{2}=$ coefficient associated with year, and $\varepsilon=$ error term with normal distribution

SSA Sub-Saharan Africa; LAC Latin American countries; NAM North America 


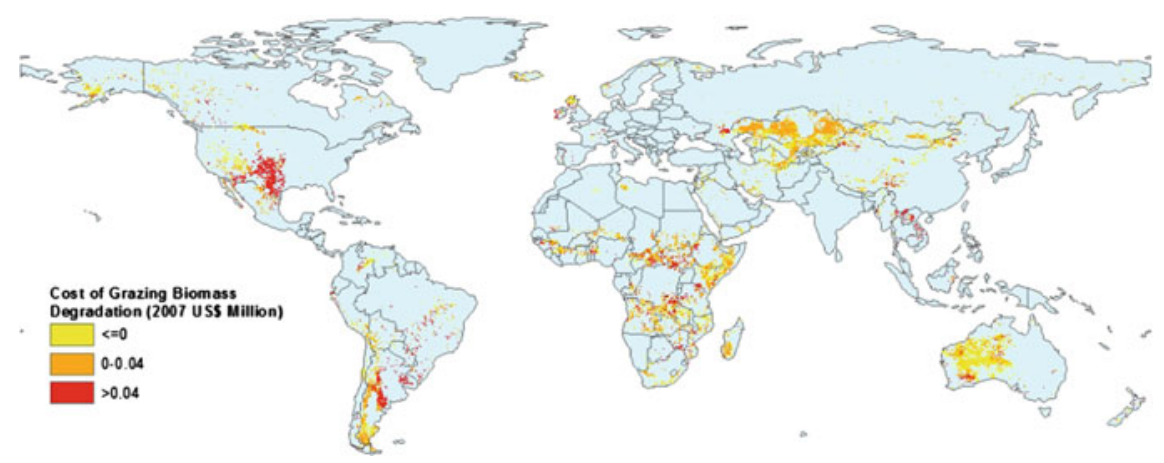

Fig. 8.3 Cost of land degradation of grazing biomass

\section{Conclusions and Implications}

This study used innovative approaches that could be used to conduct regular global assessment of grassland degradation or improvement. The approach considers only on-farm cost and ignores off-site costs- such as loss of carbon sequestration. The results reported have important implications on taking action on addressing grazing land degradation but they should be interpreted bearing in mind the weaknesses and gaps of the study.

The on-farm cost of grassland degradation is about 2007 US $\$ 6.8$ billion. North America accounts for more than $50 \%$ of the loss due to the severe land degradation and the high livestock productivity. The cost of land degradation is not reflected in the loss of productivity due to the ability of farmers in North America to use improved production technologies to maintain or increase livestock productivity. Additionally, the impact of changes in grazing land productivity on human welfare in North America is minimal given the farmers' ability to cushion such shocks using insurance, government programs, credit and other programs. Although the grazing land degradation is much more widespread in SSA, its actual cost is small due to the low livestock productivity. However, the impact on human welfare is much more severe - especially in the drylands where majority of the livestock is located and where majority of the population is below the poverty line. This implies that efforts to address grassland degradation is even more urgent in SSA. This is especially urgent given the increasing demand of livestock products and the potential to contribute to poverty reduction. Addressing grassland degradation could simultaneously reduce poverty, contribute to carbon sequestration, increase productivity of crops, provide more draft power, and other socio-economic, cultural, and ecological benefits that livestock provide. The large cost of grassland degradation, the increasing demand for livestock products, and the multiple benefits of livestock provide opportunities to take action.

Among the actions that could be taken to increase livestock productivity is to increase public budget allocation to livestock production in developing countries. 
For example, in SSA public budget allocation to livestock is only about $5 \%$. Investments in livestock productivity need to be directed to both cost-effective and amenable pasture management practices and breeding programs. Some developing countries can serve as success stories since they have successfully increased livestock productivity, which in turn have contributed to poverty reduction. The Kenyan dairy programs and Botswana's beef production demonstrate such success stories. Both countries have developed the livestock sector due to long-term policies for livestock development, which aimed at genetic improvement, disease control, strengthening domestic and international markets to allow farmers to address highly seasonal supplies, and health and safety standards (Hazell 2007). Efforts to improve grassland through controlled grazing, planting legumes, and other amenable practices will increase both livestock productivity and carbon sequestration (Henderson et al. 2015). This means the international community has the responsibility to support livestock development programs in low income countries due to large potential of carbon sequestration for improved grasslands management. For example, Henderson et al. (2015) show that improved grassland management could sequester up to $33.3 \mathrm{Tg} \mathrm{CO}_{2}$ year $^{-1}$ in SSA. Such support could be done by giving aid specifically aimed at grassland improvement.

Access to market in largely pastoral areas is low and this contributes to the low livestock productivity. Improvement of market access in grazing areas has also been shown to improve livestock productivity (Barrett 2008). Improvement of market access will have multiplier effects on rural development as it will have favorable impacts on poverty reduction, access to health and other rural services.

Open Access This chapter is distributed under the terms of the Creative Commons Attribution Noncommercial License, which permits any noncommercial use, distribution, and reproduction in any medium, provided the original author(s) and source are credited.

\section{References}

Asner, G., \& Archer, R. (2010). Livestock and carbon cycle. In H. Steinfeld., H. A. Mooney, F. Schneider \& L. E. Neville (Eds.), Livestock in a changing landscape. Drivers, consequences and responses (pp. 69-82). Scientific Committee on the Problems of the Environment (SCOPE): Island Press.

Barrett, C. B. (2008). Smallholder market participation: Concepts and evidence from eastern and southern Africa. Food Policy, 33, 299-317.

Bicheron, P., Defouny, P., Brockmann, C., Schouten, L., Vancutsem, C., Huc, M., et al. (2008). GLOBCOVER: Products description and validation report. MEDIAS-France/POSTEL: ESA Globcover Project.

Bouwman, A. F., Van der Hoek, K. W., Eickhout, B., \& Soenario, I. (2005). Exploring changes in world ruminant production systems. Agricultural Systems, 84, 121-153.

Bowman, G. R., Beauchemin, K. A., \& Shelford, J. A. (2003). Fibrolytic enzymes and parity effects on feeding behavior, salivation, and ruminal $\mathrm{pH}$ of lactating dairy cows. Journal of Dairy Science, 86(2), 565-575.

de Leeuw, P. N., \& Tothill, J. C. (1993). The concept of rangeland carrying capacity in Sub-Saharan Africa - myth or reality. In R. H. Behnke Jr., I. Scoones, C. Kerven (Eds.), Range 
Ecology at Disequilibrium. New Models of natural variability and pastoral adaptation in African Savannah (pp. 77-88). London: IIED, Overseas Development Institute.

Dong, J., Kaufmann, R. K., Myneni, R. B., Tucker, C. J., Kauppi, P. E., Liski, J., et al. (2003). Remote sensing estimates of boreal and temperate forest woody biomass: carbon pools, sources, and sinks. Remote Sensing of Environment, 84, 393-410.

Dregne, H. E. (2002). Land degradation in the drylands. Arid land research and management, 16, 99-132.

FAO. (2011a). Energy-smart food for people and climate. Rome: United nations food and agriculture organization.

FAO. (2011b). World livestock 2011-livestock in food security. Rome: United Nations Food and Agriculture Organization.

Fraser, R. H., \& Li, Z. (2002). Estimating fire-related parameters in boreal forest using SPOT VEGETATION. Remote Sensing of Environment, 82, 95-110.

Harris, R. B. (2010). Rangeland degradation on the Qinghai-Tibetan plateau: A review of the evidence of its magnitude and causes. Journal of Arid Environments, 74, 1-12.

Hazell, P. (2007). All-Africa review of experiences with commercial agriculture. Case study on livestock. Background paper for the Competitive Commercial Agriculture in Sub-Saharan Africa (CCAA) Study. http://siteresources.worldbank.org/INTAFRICA/Resources/2579941215457178567/Ch11_Livestock.pdf. Accessed Mar 2014.

Henderson, B., Gerber, P., Hilinksi, T., Falcucci, A., Ojima, D. S., \& Salvatore, M. (2015). Greenhouse gas mitigation potential of the world's grazing lands: modeling soil carbon and nitrogen fluxes of mitigation practices. Agriculture, Ecosystems \& Environment, 207, 91-100.

Hermann, S. M., Anyamba, A., \& Tucker, C. J. (2005). Recent trends in vegetation dynamics in the African Sahel and their relationship to climate. Global Environmental Change, 15, 394404.

Hoddinott, J. (2006). Shocks and their consequences across and within households in rural Zimbabwe. Journal of Development Studies, 42, 301-321.

Huete, A., Didan, K., van Leeuwen, W., Miura, T., \& Glenn, E. (2011). Moderate resolution imaging spectroradiometer vegetation indices. In B. Ramachandran, C. Justice, \& M. Abrams (Eds.), Land remote sensing and global environmental change, NASA's earth observing system and the science of ASTER and MODIS. New York: Springer.

Jin, Y., Yang, X., Qiu, J., Li, J., Gao, T., Wu, Q., et al. (2014). Remote sensing-based biomass estimation and its spatio-temporal variations in temperate grassland, Northern China. Remote Sensing, 6, 1496-1513.

Jones, P., \& Harris, I. (2008). CRU time-series (TS) high resolution gridded datasets. NCAS British Atmospheric Data Centre Climate Research Unit (CRU), University of East Anglia. http://badc.nerc.ac.uk/view/badc.nerc.ac.uk_ATOM_dataent_1256223773328276. Accessed Mar 2014.

Kitalyi, A., Mtenga, L., Morton, J. U., McLeod, A., Thornton, P., Dorward, A., et al. (2005). Why keep livestock if you are poor? In E. Owen, A. Kitalyi, N. Jayasuriay, \& T. Smith (Eds.), Livestock and wealth creation: Improving the husbandry of animals kept by resource-poor people in developing countries (pp. 13-27). Nottingham, UK: Nottingham University Press.

Lalonde, L. G., \& Sukigara, T. (1997). Livestock development planning system version 2 user's guide. Rome: United Nations Food and Agriculture Organization.

Le Houérou, H. N., \& Hoste, H. (1977). Rangeland production and annual rainfall relations in the mediterranean basin and in the African Sahelo-Sudanian zone. Journal of Range Managements, 30, 181-189.

Le, Q. B., Nkonya, E., Mirzabaev, A. (2014). Biomass productivity-based mapping of global land degradation hotspots. ZEF-Discussion Papers on Development Policy No. 193. University of Bonn.

Livestock in Development. (1999). Livestock in poverty-focused development. LID, Somerset, UK: Crewkerne.

LP DAAC (Land Processes Distributed Active Archive Center) (2011). MODIS/AQUA MYD13C1 Vegetation Indices 16-DAY L3 Global 0.05Deg CMG. Collection 5. 
Moll, H. A. J. (2005). Costs and benefits of livestock systems and the role of market and nonmarket relationships. Agricultural Economics, 32, 181-193.

Nabuurs, G. J. (2004). Current consequences of past actions: how to separate direct from indirect. In C. B. Field \& M. R. Raupach (Eds.), The global carbon cycle (pp. 317-326). Washington, DC: Island Press.

New, M., Hulme, M., \& Jones, P. (2000). Representing twentieth-century space-time climate variability. Part II: development of 1901-96 monthly grids of terrestrial surface climate. Journal of Climate, 13, 2217-2238.

Nicholson, S. E., Davenport, M. L., \& Malo, A. R. (1990). A comparison of the vegetation response to rainfall in the Sahel and East Africa, using normalized difference vegetation index from NOAA AVHRR. Climate Change, 17, 209-241.

Penning de Vries, F. W. T. \& Djiteye, M. A. (1982). La productivite des paturages saheliens: une etude des sols, des vegetations et de l'exploitation de cette ressource naturelle.

Pieri, C. (1989). Fertilité des terres de savanes. Bilan de trente ans de recherche et de développement agricole au sud du Sahara. Ministère de la Coopération/CIRAD/IRAT, Paris.

Potter, P., \& Ramankutty, N. (2010). Characterizing the spatial patterns of global fertilizer application and manure production. Earth Interactions, 14, 1-22.

Quinlan, T. (1995). Grassland degradation and livestock rearing in Lesotho. Journal of Southern African Studies, 21, 491-507.

Rahetlah, V. B., Salgado, P., Andrianarisoa, B., Tillard, E., Razafindrazaka, H., Mézo, L. L., et al. (2014). Relationship between normalized difference vegetation index (NDVI) and forage biomass yield in the Vakinankaratra region, Madagascar. Livestock Research for Rural Development. 26: Article \#95.

Randolph, T. F., Schelling, E., Grace, E., Nicholson, C. F., Leroy, J. L., Cole, D. C., et al. (2007). Invited review: Role of livestock in human nutrition and health for poverty reduction in developing countries. Journal of Animal Science, 85, 2788-2800.

Ren, H., \& Zhou, G. (2014). Determination of green above ground biomass in desert steppe using litter-soil-adjusted vegetation index. European Journal of Remote sensing, 47, 611-625.

Requier-Desjardins, M. (2006). The Economic costs of desertification: A first survey of some cases in Africa. International Journal of Sustainable Development, 9, 199-209.

Robinson, T. P., Thornton P. K., Franceschini, G., Kruska, R. L., Chiozza, F., Notenbaert, A., et al. (2011). Global livestock production systems. Rome, Food and Agriculture Organization of the United Nations (FAO) and International Livestock Research Institute (ILRI), $152 \mathrm{p}$.

Robinson, T. P., \& Pozzi, F. (2011). Mapping supply and demand for animal-source foods to 2030, Animal Production and Health Working Paper. No. 2. Rome.

Robinson, T. P., William Wint, G. R., Conchedda, C., Van Boeckel, T. P., Ercoli, V., Palamara, E., et al. (2014). Mapping the global distribution of livestock. Plos One. doi:10.1371/journal. pone.0096084.

Roy, P. S., \& Ravan, S. A. (1996). Biomass estimation using satellite remote sensing data-An investigation on possible approaches for natural forest. Journal of Bioscience, 21, 535-561.

Sere and Steinfeld, (1996). World livestock production systems: current status, issues and trends. Animal production and health paper No127. FAO. Rome.

Sheldrick, W. F., Syers, J. K., \& Lingard, J. (2004). Contribution of livestock extreta to nutrient balances. Nutrient Cycling Agroecosystems, 66, 119-131.

Steinfeld, H., Gerber, P., Wassenaar, T., Castel, V., Rosales, M., \& De Haan, C. (2006). Livestock's long shadow: Environmental issues and options. Rome: United Nations Food and Agriculture Organization.

Thoma, D. P., Bailey, D. W., Long, D. S., Nielsen, G. A., Henry, M. P., Breneman, M. C., et al. (2002). Short-term monitoring of rangeland forage conditions with AVHRR imagery. Journal of Range Management, 55, 383-389.

Tomppo, E., Nilsson, M., Rosengren, M., Aalto, P., \& Kennedy, P. (2002). Simultaneous use of Landsat-TM and IRS-1C WiFS data in estimating large area tree stem volume and aboveground biomass. Remote Sensing of Environment, 82, 156-171. 
Wainwright, J., \& Mulligan, M. (2005). Modelling and model building. In J. Wainwright \& M. Mulligan (Eds.), Environmental modelling: Finding simplicity in complexity (pp. 7-74). Chichester, England: John Wiley \& Sons.

Wirsenius, S., Azar, C., \& Berndes, G. (2010). How much land is needed for global food production under scenarios of dietary changes and livestock productivity increases in 2030? Agricultural Systems, 103, 621-638.

Zhao, F., Xu, B., Yang, X., Jin, Y., Li, J., Xia, L., et al. (2014). Remote sensing estimates of grassland aboveground biomass based on MODIS net primary productivity (NPP): A case study in the Xilingol grassland of Northern China. International Journal of Remote Sensing, 6, $5368-5386$. 